Marquette University

e-Publications@Marquette

4-1-2008

Covert Marketing Unmasked: A Legal and Regulatory Guide for Practices that Mask Marketing Messages

Ross D. Petty

Babson College

J. Craig Andrews

Marquette University, craig.andrews@marquette.edu

Published Version. Journal of Public Policy \& Marketing, Vol. 27, No. 1 (Spring 2008): 7-18. DOI. (C) 2008 American Marketing Association. Used with permission. 


\title{
Covert Marketing Unmasked: A Legal and Regulatory Guide for Practices That Mask Marketing Messages
}

\author{
Ross D. Petty and J. Craig Andrews
}

\begin{abstract}
Masked marketing - one form of covert marketing-involves marketing communications that appear to be from independent third parties rather than from product marketers. This article presents a typology of masked marketing practices, illustrating whether they may be deceptive to consumers. To accomplish this, the authors apply the Federal Trade Commission's three-part definition of deception (i.e., misleadingness, reasonable consumer, and materiality) in the evaluation of such practices. The article concludes with policy recommendations including areas for further research.
\end{abstract}

Keywords: covert marketing, advertising, deception, Federal Trade Commission, information disclosure

I $\mathrm{t}$ is estimated that consumers are bombarded by some 5000 overt marketing communications daily but are so accustomed to such messages that they consciously perceive only 1\%-2\% of them (Pringle 2004, pp. 60-61). Not only can consumers not possibly process so many messages, but surveys also indicate that, in general, most consumers are skeptical of marketing messages (Calfee and Ringold 1994; Obermiller and Spangenberg 2000; Obermiller, Spangenberg, and MacLachlin 2005). In addition, a recent set of studies suggests that consumers who are actually deceived by an advertisement become skeptical of all advertising but not skeptical of product information provided by nonmarketing sources (Darke and Ritchie 2007). For these reasons, consumers tend to ignore most marketing messages. Covert marketers hope to avoid both consumer disinterest and skepticism of marketing communications by communicating in ways that are perceived as not being marketing communications (Kaikati and Kaikati 2004). In addition, some methods of masked marketing, such as product placements in television shows, allow for the circumvention of advertising-avoiding technology. Some methods also have the added advantage of being less expensive than conventional methods of advertising.

Masked marketing is one form of covert marketing. We suggest that there are at least two other forms of covert marketing. The first is referred to as "mole marketing"; this is when marketers attempt to reach potential consumers with a recognizable marketing message but through unconven-

Ross D. Petty is Professor of Marketing Law, Babson College (e-mail: petty@babson.edu). J. Craig Andrews is Professor and Charles $\mathrm{H}$. Kellstadt Chair in Marketing, College of Business Administration, Marquette University (e-mail: craig.andrews@marquette.edu). The authors thank Michael Mazis, the three anonymous JPP\&M reviewers, and the special section editor for comments on previous drafts of this article.

(C) 2008, American Marketing Association

ISSN: 0743-9156 (print), 1547-7207 (electronic) tional means. Examples of such practices include ad-ware surreptitiously placed on consumer computers to send advertising messages while consumers are searching the Web and advertising messages sent to cell phones, at least in the United States where the practice is not yet familiar to consumers (Petty 2003). We refer to a second set of practices as "mental marketing" because the marketing messages are not consciously perceived or evaluated but still might influence behavior. Examples of this type of practice include the much-discredited subliminal advertising (e.g., Broyles 2006; Moore 1982) and the use of nonverbal sensory stimuli to predispose consumers favorably toward products (Lindstrom 2005), including pictorial imagery (Kisielius and Sternthal 1986; Mitchell and Olson 1981). Together with masked marketing, we refer to these sets of practices as the "three Ms" of covert marketing.

We define "masked marketing" as marketing communications that appear not to be marketing communications. These communications may be masked as to their commercial source, their commercial message, or both. Such masking raises public policy concerns because though most consumers are skeptical of advertising, they are less skeptical about information that appears to be independent from marketers (Balasubramanian 1994; Darke and Ritchie 2007). For example, a recent global survey of Internet users found that $78 \%$ trusted recommendations from consumers, but only $56 \%$ trusted television and magazine advertising (Nielsen 2007). Indeed, many consumers have developed methods to cope with overt attempts at persuasion (e.g., "schemer schemas"; Friestad and Wright 1994). In addition, some forms of masked marketing appear as personal communications and may target groups that are more susceptible to interpersonal influence than typical consumers (Bearden, Netemeyer, and Teel 1989; Churchill and Moschis 1979; Phillips and Sternthal 1977).

Although terms such as "buzz" and "viral" marketing are relatively new to the lexicon, masked marketing has been 
practiced and regulated for more than 75 years. For example, in 1936, a court held that endorsements by apparently independent expert organization were deceptive because the organization was not financially independent from the advertiser (Gynex Corp. v. Dilex Inst. of Feminine Hygiene 1936). The next year, the Supreme Court affirmed the Federal Trade Commission's (FTC) condemnation as an unfair method of competition of the practice of sales agents gaining entrance to homes by purporting to deliver only a free prize or booklet but then making the sales pitch once they had gained access (FTC v. Standard Education Society 1937). Later FTC cases have also condemned marketing messages as deceptive for appearing to be checks (United States v. Reader's Digest Association 1981), even from the government (A.A. Friedman Co. 1968), or prize awards (National Housewares Inc. 1977).

Although the practice of masked marketing predates the FTC's deception authority (granted by Congress in 1938), virtually any legal challenge to such practices today would occur under this authority. The commission's "Policy Statement on Deception" (FTC 1983) presents a thoughtful, general analysis of deception, though largely in the context of misleading product claims. The statement addresses masked marketing when it specifically notes with apparent approval that the FTC found deception when a sales agent misrepresented the purpose of the initial contact with potential customers (Encyclopaedia Britannica Inc. v. FTC 1979).

This article unmasks masked marketing techniques and examines the legal and regulatory issues associated with such practices. To do so, it follows the FTC's three-part deception analysis: Is the practice likely to mislead consumers? Are misled consumers behaving reasonably? and Is the practice material (i.e., likely to affect consumer conduct)? The article concludes with policy recommendations and suggestions for further research.

\section{The Misleading Nature of Masked Marketing Practices}

Under the current "Policy Statement on Deception" (FTC 1983), the first requirement for deception is that there must be a representation, omission, or practice that is "likely to mislead" the consumer (see also Ford and Calfee 1986; Shimp 2007). A "misrepresentation" is defined as an express or implied statement contrary to fact, whereas a "misleading omission" occurs when qualifying information necessary to prevent a practice, claim, representation, or reasonable expectation or belief from being misleading is not disclosed. As applied to masked marketing practices, the first question is whether there is an express or implied representation or an omission that the communication is not a marketing communication. If a poser, buzz, or viral agent or an advertorial denied any commercial connection or marketing purpose, there would be an express representation that was false. However, most of the examples we discuss subsequently involve an implied representation that the message is not marketing related because the communication appears to be of a nonmarketing nature. Even if there is not an implied representation of a nonmarketing origin to the communication, the omission of the marketing origin is probably material to reasonable consumers, as we discuss subsequently. To aid in the evaluation of misleadingness of
Table 1. A Typology of Masked Marketing Practices

\begin{tabular}{lc}
\hline Practice & Description \\
\hline $\begin{array}{c}\text { Posers (disguised } \\
\text { communicator) }\end{array}$ & $\begin{array}{c}\text { Actors or salespeople who pretend to } \\
\text { be ordinary people or researchers } \\
\text { conducting a survey to explain } \\
\text { product benefits and give potential } \\
\text { consumers the chance to examine, } \\
\text { sample, or use a product. }\end{array}$
\end{tabular}
Buzz and viral marketing (disguised communicator)

Advertorials (disguised format)

Ad-sults from a search engine or other query (disguised format)

Recruitment of people to talk about products through free samples or discounts before the product is available to the general public and suggestions on what to say and how to approach people about the product. Some refer to this as viral marketing when the contact with potential consumers is done electronically.

\section{Advertisements that appear to be information from an independent source, such as prepared television news stories; infomercials that appear to be consumer television shows; and print advertisements that appear to be editorial content.}

Use of invisible metatags by a marketer or the sale of priority by a search engine of the results from a particular query when the results are not identified as biased.

Urgent ad-formation (disguised format)

\section{Advertainment (disguised format)}

\begin{abstract}
Advertisements that appear in the form of important account information from firms with an existing business relationship, government notices, sweepstakes prize notices, or checks that are simply discount coupons.
\end{abstract}

Product and advertising placement in television shows, at sporting events, and in video games.

masked marketing practices, Table 1 organizes such practices into six categories. The first two categories involve source masking, and the latter four involve masking the message format. We should note, however, that not all disguises are deceptive to consumers. Most consumers are familiar with actors in television commercials portraying ordinary consumers and product users (e.g., Mr. Whipple for Charmin toilet tissue, Mr. Goodwrench for General Motors auto service, and the Maytag repairman).

\section{Posers}

In contrast to actors in television advertisements, some marketing companies hire paid actors or marketing agents to pretend that they are ordinary product users and to talk to people about the products being marketed. Such actors or agents may be called posers. Vespa scooters hired models and actors to cruise night clubs and cafés on their trendy machines and "talk up" the product when they could. Perhaps the most infamous example of posers is Sony Erics- 
son's use of 120 actors at popular tourist locations posing as tourists and asking people to take their picture using the phone and then taking that opportunity to explain how the camera aspect and its features worked (Dobele, Toleman, and Beverlan 2005). This particular incident, as well as similar practices, was featured on the CBS news show 60 Minutes (2004). Potential consumers in these situations were not told at the time of the marketing purpose of these paid actors, and some seemed upset when they learned about this purpose during interviews for the show. Similarly, Sony set up a blog called "All I want for Christmas is a PSP" (PlayStation Portable), but when consumers discovered that Sony's advertising agency owned the domain name, it faced negative publicity (Goodman 2007). Posers may also be celebrities who are paid to promote a product in the course of their regular celebrity interviews (Bandler 2005). Kaikati and Kaikati (2004, p. 12) describe three morning talk show interviews with celebrities in which they each described medical problems and the product that helped them without disclosing that they were paid to promote the product.

Although the FTC has not taken action against any of these examples, it pursued Georgetown Publishing for what appeared to be a personal communication on a small adhesive yellow note attached that appeared handwritten: "Try this. It works! (signed) J." Recipients probably pondered who among their acquaintances with an initial of " $\mathrm{J}$ " might have sent this message. This communication also was disguised to appear as a personal mailing of what appeared to be an independent book review torn from a magazine and ordering information for the book on public speaking that was the subject of a book review. Georgetown agreed not to misrepresent that future advertisements were not advertisements (Georgetown Publishing House LP Inc. 1996). With the advent of Internet sales, today's posers often do not need to reveal that they are paid marketing agents, unlike the commissioned sales agents who needed to close a sale to earn the commission and therefore eventually revealed their marketing purpose. Today, consumers are likely to be misled by such low-key appearances and the lack of clear and conspicuous disclosure.

\section{Buzz and Viral Marketing}

Buzz and viral marketing include techniques designed to encourage word-of-mouth promotion by consumers. Viral marketing is often defined as buzz marketing conducted by electronic technology, such as e-mail, chat rooms, blogs, and text messaging (Dobele, Toleman, and Beverland 2005). Kaikati and Kaikati (2004, p. 9) provide an even simpler definition of viral marketing: "word of mouth via a digital platform." Estimates place the amount of money being spent on buzz marketing at \$40-\$60 million in 2004, up $100 \%$ from the prior year (Creamer 2005). Advertising Age estimates industry size to be between $\$ 100$ million and $\$ 150$ million (Horowitz 2005).

In the case of both buzz and viral marketing, the goal is to encourage conversation about the product. Buzz and viral agents differ from posers in that the former are actual consumers and the latter are hired actors or marketing representatives. However, in a blog or chat room, it is difficult to tell the identity of the person posting. Is he or she a consumer who was given a product sample and asked to talk about it with friends, or is he or she a marketing agent, perhaps one that works full time for the company marketing the product?

The practices range from simply offering a trendy product, such as Chrysler's PT Cruiser, to Miami rental car companies trying to get consumers to rent cars and hopefully to talk to others about their experience, to encouraging consumers to "talk up" a product by providing rewards and/ or "talking points." One advantage of viral marketing is that video or audio files can be sent to opinion leaders with the hope that they will resend them to others. For example, Lee Jeans sent 200,000 male Web surfers amateurish video clips from three purportedly amateur filmmakers. The purported filmmakers turned out to be characters in an online video game. More than 100,000 people were sufficiently intrigued to get a Lee product code to watch the videos, and Lee sales increased 20\% (Khermouch and Green 2001). A second advantage of technology in viral marketing is that agents can appear in more places virtually. They can be in chat rooms, on bulletin boards and blogs, and sending e-mail or text messages to friends.

When buzz agents are involved, these programs typically provide suggestions to agents about product selling points and general communication to consumers. However, they typically do not require adherence to a script or particular program, and agents enjoy being the first to receive and try new products, sometimes through discounts on the items (Walker 2004). More organized programs recruit a large continuing group of thought leaders. These programs become controversial when they offer rewards to agents but do not require that they disclose this commercial connection. Procter \& Gamble's group, Tremor, was featured in a recent complaint to the FTC by Commercial Alert (2005) for inadequate disclosure to parents involving buzz marketing activities using teens and children. In contrast, BzzAgent found that its campaigns were more effective when agents revealed that they were working for a particular client (Creamer 2005). A recent unpublished study noted that important outcome measures, such as credibility, inquiry, use, purchase, and pass-along communication, were not negatively affected by a buzz agent disclosing his or her affiliation (Carl 2006).

To the extent that buzz and viral agents believe that they are presenting their honest opinions, this practice may be less troubling than posers. It might be argued that free samples or discount coupons are less biasing than cash compensation, and perhaps consumers expect some opinion leaders to get free samples. Thus, this level of compensation or affiliation may not be misleading to reasonable consumers and need not be disclosed. To be effective, buzz or viral marketing is typically spread among friends who know one another and may be more likely to know that the agent is part of a marketing program. However, viral marketing in blogs or spam is more likely to occur from an unknown source who appears to be an ordinary person not related to a marketing campaign.

\section{Advertorials}

Advertorials are marketing messages disguised to appear as independently produced media content. An increasingly popular example is the video news release that is produced by a marketer but is shown during a news broadcast. The 
Federal Communications Commission (FCC) recently fined Comcast for airing such a release without identifying the commercial sponsor (Comcast Corp. 2007). In Georgetown Publishing House (1996), the poser's apparently personal message included a detailed advertisement that appeared to be an independent magazine review of the product rather than an advertisement. Mail solicitations are increasingly designed to look like personal mail, such as a greeting card with a handwritten address and a postage stamp rather than a postal meter cancellation, but these maskings have not attracted legal challenge in and of themselves (Abelson 2005). In addition, the American Society of Magazine Editors guidelines recommend against placing advertisements next to related editorial material in any way that suggests endorsement. Furthermore, some advertisements deliberately mimic editorial content of particular magazines (Steinberg and Bandler 2004).

Marketing messages that appear as television shows are commonly known as infomercials. The FTC has pursued infomercials for being deceptively formatted as independent television shows since at least 1989 (e.g., JS\&A Group Inc. 1989). Television infomercials have also been challenged as false advertising for making false product claims (but not for being deceptively formatted) by competitors under section 43(a) of the Lanham Act (e.g., Media Arts Int'l Ltd. v. Trillium Health Products 1992). In 2004, the FTC again took action against two infomercials that appeared as independent television programs, with only brief disclosures at the beginning and end that this was a "paid advertisement" (FTC v. Direct Marketing Concepts Inc. 2004; FTC v. Window Rock Enterprises Inc. et al. 2004). These infomercials also included "guest" doctors, who were principals in the marketing firm, and supposedly independent "viewer" questions, and they asked viewers to mention the name of the show to receive a discount when calling to order. In Braswell et al. (2006), the FTC found false and misleading dietary supplement claims touting medical and scientific "breakthroughs" targeting the elderly made through the "Journal of Longevity," a direct mail advertisement purporting to be a health information magazine. However, distributing "magazines" that are actually $100 \%$ marketing vehicles is not misleading as long as they are identified as such. Collins (2004) notes that there are approximately 116,000 custom "magazines" now published by marketers to tout their wares, such as B Magazine, published by Bloomingdales.

An example of the evolution of the blurring between advertising and editorial content is the occasional advertisement that is readily identified as such but turns out to be for an unexpected product or service. For example, MercedesBenz produced what appeared to be a preview for an action movie shown in British movie theaters. However, when visiting a Web site that was suggested in the preview, consumers learned there was not a movie but an advertisement for Mercedes-Benz (Kaikati and Kaikati 2004, p. 13). This practice only misleads consumers briefly because they recognize the Web site as selling Mercedes automobiles.

\section{Ad-sults from a Query}

Metatags, language placed on Web sites that is invisible to users but is read by search engines, allows a seller to improve its rank ordering in search results by leveraging repeat usage on its home page. The seller might even be ranked above the brand owner, thus misdirecting consumers. A recent Ninth Circuit Court decision carefully analyzed metatag use. It rejected traditional trademark infringement likelihood of confusion from metatag use. The court reasoned that search engines provide a list of results, and consumers are used to trying several before finding the specific one they are seeking. As long as the domain name is distinctive, consumers are not confused by incorrect results. Nevertheless, the court found likelihood of initialinterest confusion from metatag use and issued an injunction. It argued that initial-interest confusion was actionable under trademark law even if no long-term source confusion resulted. After being directed to the incorrect Web site of a competitor, the consumer may decide to use it instead of the one he or she was originally seeking, thus injuring the trademark owner (Brookfield Communications v. West Coast Entertainment Corporation 1999). Search engines soon realized that they could sell search result priorities, and several experimented with various methods of doing so. However, in response to a complaint, the FTC warned search engine firms that they should distinguish neutral search engine results from paid-for advertising (FTC 2002; Kopytoff 2002). Google now does so by identifying paid search results as "sponsored links."

\section{Urgent Ad-formation}

This category differs slightly from ad-sults because the latter appears to be information requested by the consumer, whereas urgent ad-formation is advertising that appears to be urgent nonadvertising information that was not requested but might be of interest to most consumers. Advertising that looks like important or urgent information can take several forms: an important notice about the consumer's account, a notice from what appears to be an official government source, a notice of winning a sweepstakes prize, or something that appears to be a check; in reality, though, such "information" is an order form or discount coupon. An approach that seems currently popular with credit card companies is to send notices with "important information about your account" that are nothing more than "checks" that may be used to access the line of credit. Similar misleading practices are used in telemarketing and e-mail (Direct Marketing Association 2005).

With the advent of Internet use, some advertisers have tried to make pop-up advertising look like an official system warning. The National Advertising Division of the Council of Better Business Bureaus has condemned the use of advertisements disguised as system warnings and has stated broadly that advertisers have an obligation to present their product claims in a form that consumers will recognize as advertising (Bonzi.com Software 2001).

Perhaps the most famous, recent examples of this practice are the magazine subscription companies' sweepstake notifications. These notices allegedly appear to tell consumers that they were one of only a few finalists. Similar contests often proclaim that consumers are "guaranteed" to win at least one listed prize. Although many consumers are familiar with these promotions and are not misled, an 88year-old man cashed in his life savings to buy an airplane ticket to Florida to collect his winnings. The magazine companies agreed with state attorneys general to tone down 
their implications of winning and have lost sales as a result (Cyr 1999). In most cases, consumers may recognize sweepstakes as marketing communications. Sweepstakes also are subject to specific rules, mostly at the state level, that require them to disclose prizes and the odds of winning to avoid being deceptive (Taylor and Kopp 1991).

\section{Advertainment}

Advertainment practices are dominated by what are commonly called "product placements" in television shows and movies. The value of product placements, including paid, barter, and gratis placements, was estimated at $\$ 3.5$ billion in 2004 and was expected to grow to $\$ 4.2$ billion in 2005 . Paid placements account for $29 \%$ of this value (Balasubramanian, Karrh, and Patwardhan 2006). Nielsen Media Research reports that in the first quarter of 2005, the ten television programs with the most product placements accounted for nearly 13,000 placements-more than half the total placements in 2004 (Enright 2005). Product placements are expected to be used in approximately $75 \%$ of prime-time network television shows and have become part of the marketing mix for more than 1000 U.S. brands (Russell and Stern 2006).

A new form of product placement began in November 2005 when Shockwave.com was believed to be among the first companies to announce programs for advertisers that want to insert advertisements into online video games. Shockwave.com hosts more than 200 games and claims more than 20 million visitors monthly to its Web site. Its advertising program measures impressions for each advertisement. The advertisements are incorporated into the game format, such as billboard advertisements around a virtual skate park in a skateboarding game (Associated Press 2005). Video game advertising was estimated at \$186 million in 2005 and may reach $\$ 875$ million by 2008 (Vranica 2005). Moore and Rideout (2007) also note that games are common on marketers' Web sites. They find that the majority of food brands advertised to children also are promoted to them through food-marketer Web sites, most of which offer at least one online game.

As product placements continue, they may evolve in two directions. First, the line between entertainment with a product placement and advertising that looks like entertainment is blurred. Not only are many video games accepting product placements, but critics also note that some video games are predominantly based on advertising, and such "advergaming" is often targeted to children (Menin 2005; Teinowitz 2005). Second, placements are evolving to be more "active" in nature. As we noted previously, a talk show guest who pitches a particular product is more akin to being a poser than a mere product placement. However, what if a movie or television character either uses a name brand product is such a way as to demonstrate its performance or durability or describes a product in favorable terms? Are consumers likely to recognize such "active" placements as advertising and consider them accordingly? Would a fan of Mad TV recognize the paid placement of Toyota Yaris in monthly skits on the show before the model was available (Sutton and Zack 2006)?

Advertainment as a category has at least some practices whose marketing nature is reasonably clear. Consumers might well expect that advertisements, such as billboards, that appear in the background of video games and movies are paid-for advertisements. Adults also should recognize when "host selling" (Campbell 2006) is occurring, as when a talk show host holds up a product and describes its features and benefits. Although this may be mole marketing, or advertising in an unexpected place, consumers should not be misled as to the nature of the advertising. However, a movie or television show with a character using a particular product may not appear to consumers to be advertising for that product. A Brazilian study indicates that viewers may not even assign promotional meanings to products placed in television shows (La Pastina 2001).

Commercial Alert (2003b) filed a petition with the FTC (and separately with the FCC) requesting that the FTC require that advertisers disclose product placements in a clear and conspicuous manner when they appear on the television screen. The FTC has responded to the petition in a letter to Commercial Alert (2005) that it has taken action when misleading objective representations about the product/service have been made in program-length infomercials (JS\&A Group Inc. 1989; Synchronal Corporation 1994), through misleading formats (Braswell et al. 2006; Georgetown Publishing House 1996), on search engines, and in endorsements that lack disclosure of material connections. The key phrase in the FTC's (2005, p. 3) response to Commercial Alert is when "objective claims about the product's attributes" have been made. Thus, the FTC has not taken action (at this time) against passive product placements because of (1) a lack of objective claims being made about such product placements and (2) a lack of evidence that such objective claims might be misleading under the deception policy statement. This reasoning is also consistent with the nature of extrinsic evidence in FTC deception cases that focuses on the net impression of such advertised claims (cf. Andrews and Maronick 1995; Maronick 1990). This phrase in the FTC's response also raises the question whether any masked marketing techniques should be challenged by the FTC if it is not also challenging deceptive product claims made in the masked marketing format. We address this question in the following sections.

\section{The Perspective of Reasonable Consumers}

The second requirement for deception in the FTC's (1983) "Policy Statement on Deception" is that the practice is examined from the perspective of the consumer acting reasonably under the circumstances. If the representation or practice affects or is directed to a particular group (e.g., target market), the FTC will examine reasonableness from the perspective of that group. For example, young children may be less likely to understand the selling intent behind advertisers' Web site games (Moore and Rideout 2007). Although much of the deception statement discussion of reasonable consumers examines consumer interpretation of product claims, the same rule appears to apply to masked marketing. The statement specifically notes with apparent approval that the FTC found deception when a sales representative misrepresented the purpose of the initial contact with potential customers (Encyclopaedia Britannica Inc. $v$. FTC 1979). Presumably, reasonable consumers were likely to be deceived by the initial contact. 
Ford and Calfee (1986) point out that reasonable consumers are not necessarily rational from the perspective of economics. Indeed, it is well recognized that people use heuristic shortcuts to make complex decisions (Hammond, Keeney, and Raiffa 2006; Petty and Cacioppo 1986). A common heuristic, which we noted in the introduction, is to be skeptical of marketing messages and resist being persuaded by them while trusting personal communications to a greater degree (Balasubramanian 1994; Darke and Ritchie 2007). This is a reasonable approach for consumers to deal with advertising clutter and misleading advertising, even though in some circumstances, it may lead consumers to ignore marketing messages for products they would buy if they had complete and accurate information about the products.

Certain laws and rules recognize the reasonableness of consumer skepticism of advertising by prohibiting deception regarding the marketing nature of communications. For this reason, the FTC Telemarketing Rule (16 C.F.R § 310.4[d][2]) (but not the FTC's Door-to-Door Sales Rule [16 C.F.R. § 429]) requires that sellers identify themselves promptly and that the purpose of the call is to sell goods or services, and the CAN-SPAM Act of 2003 (15 U.S.C. 7704; Controlling the Assault of Non-Solicited Pornography and Marketing) prohibits deceptive "from" and "subject" lines. However, some state laws, now preempted by the federal act, would have required an "ADV" prefix in the subject line for the earliest possible notification to consumers of the commercial content of the message. Similarly, FCC Commissioner Adelstein (2005) indicates that prior FCC actions require disclosure of the source of video news releases. He also notes that current FCC regulations require disclosure of paid product placements. As of this writing, the FCC has not responded to a petition to regulate product placements more tightly (Commercial Alert 2003a).

Some forms of masked marketing are discoverable as such by diligent or experienced consumers. Infomercials now often contain some disclosure, perhaps only at the beginning or the end, that they are paid-for programming. Advertisements that appear to be magazine articles or even entire magazines often disclose their true nature somewhere in fine print. Sweepstakes notifications usually contain small print explaining the odds (as required by most states) and therefore identify the likely prize to be won and the loss probability of winning more desirable prizes. Given the limited amount of time consumers spend paying attention to advertising, there is an open question whether consumers who miss such disclosures are behaving reasonably under the deception statement. It probably is true that any sort of reasonably noticeable disclosure makes FTC action less likely. The FTC requires disclosures to be "clear and conspicuous" in its rules and case law; however, few current televised ad disclosures meet the criteria (Hoy and Andrews 2004).

In situations in which the truth is eventually revealed, often not voluntarily by the marketer, there typically is some negative publicity for the marketer, as when WalMart failed to disclose its funding for a recreational vehicle cross-country trip and blog site that favorably reviewed the local Wal-Mart at each stop (Gogoi 2006). However, it is not clear whether such negative publicity affects future sales (i.e., was the deception material to purchasing decisions); however, a clear and conspicuous disclosure would appear to resolve the question of possible deception. Some marketers believe that the identification of agents as such is critical to long-term success and that paid-for undercover posers are disingenuous (Walker 2004). Similar to the FTC endorsement guidelines, the Word of Mouth Marketing Association recommends disclosure in its new draft code of ethics (available at http://www.womma.org/ethicscode. htm).

Both the FTC's deception statement and its endorsement guidelines (issued in 1980) reflect the notion that reasonable consumers may be less skeptical of personal opinions than of advertising claims. Both state that claims phrased as opinions may be deceptive if they are not honestly held or if the basis of the opinion is misrepresented (16 C.F.R. $\S$ 255.1[a]). The guidelines are not binding by themselves but suggest that endorsement and testimonial statements in advertising should reflect the honest beliefs, opinions, and experiences of the endorser. For example, endorsers who claim that they have used the product must have actually used the product (16 C.F.R. $\S 255.1[b]$ ).

Because consumers might be misled into believing that an endorsement is being made solely out of genuine enthusiasm for the product, the guidelines also require the disclosure of any unexpected commercial connection between the marketer and the endorser (16 C.F.R. $§ ~ 255.5)$. Furthermore, the guidelines state that endorsers represented directly or by implication to be actual consumers should be actual consumers. Otherwise, the marketer should disclose that the people are not actual consumers but rather family members, business associates, and so forth, in relationship to the company or its owner(s) (16 C.F.R. $§ 255.2[\mathrm{~b}]$ ). In its response to Commercial Alert's petition on buzz marketing, the FTC's associate director for advertising practices cited the guidelines to indicate that nondisclosure of the sponsorship relationship between marketer and agent would be deceptive. The FTC (2006) would consider action on a case-by-case basis.

Unfortunately, the guidelines offer little as to what might constitute an unexpected commercial connection. The Pat Boone consent order originally required that the singer/ actor disclose his financial interest in a venture when he was paid on a per-bottle basis rather than paid a standard fixed fee for filming the commercial. However, the order was later modified to remove this disclosure requirement (Cooga Mooga Inc. 1978). The third example presented in $\S 255.5$ of the endorsement guidelines is of a restaurant that advertises that patrons will be interviewed about the food for possible appearance in television advertising. Because that incentive might affect the weight or credibility of a patron's endorsement in the minds of consumers, it should be disclosed in the advertisements. This suggests that incentives given to posers and buzz and viral agents, such as free product samples or significant price reductions, should be disclosed so that consumers exposed to marketing messages from these sources can evaluate their credibility.

Although the guidelines are expressly limited to endorsements and testimonials that appear in advertising, there is no policy reason that the same principles should not apply to statements made in the masked marketing context. 
Indeed, the guidelines assume that consumers will recognize the marketing context of the statements, but masked marketing intentionally attempts to hide that context. If reasonable consumers are less skeptical of masked marketing messages than readily identifiable marketing messages, there is a greater reason to apply the protections of the endorsement guidelines to masked marketing as the FTC (2006) implicitly recognizes.

\section{Materiality}

The third requirement of the deception statement is materiality - that is, the representation, omission, or practice is one that is likely to affect consumer choice or conduct toward the product. The deception statement notes that the FTC will presume materiality for several types of claims and situations (e.g., express claims; seller knowledge or intent in making the claims; claims about health, safety, or other important characteristics), but it is silent as to whether such a presumption would be applied to masked marketing. However, the marketing literature on consumer skepticism of advertising and trust of personal communications and the deception statement's apparent approval of the FTC's case against encyclopedia salespeople both suggest that masking the marketing nature of communications would be considered material for reasonable consumers (Encyclopaedia Britannica Inc. v. FTC 1979).

A strong argument also can be made that marketers intend to disguise the marketing nature of the communications, satisfying the presumption of materiality in the statement. The goal of masked marketing is to have consumers pay attention to the communication but not realize that it is a marketing message that they otherwise might ignore. The urgent ad-formation category of practices goes one step further. Not only does the marketer intend to disguise the marketing purpose of the message, but he or she also tries to make the disguise appear material to consumers.

The few marketing studies on masked marketing practices have shown that the practices tend to influence consumer behavior. For example, an empirical study found that game players remember $25 \%-30 \%$ of the brands immediately after playing and still remembered $10 \%-15 \%$ of the brands five months later (Nelson 2002). Similarly, a recent comprehensive study of product placements found that placements may increase product recall and even favorably change attitude toward the brand (Balasubramanian, Karrh, and Patwardhan 2006). Despite these changes in consumer recall, we acknowledge that many of these studies suggest less influence on intent to purchase. Further research has suggested that a product's connection to characters in a television show and the viewer's relationship with the characters also influence viewers' attitudes toward products placed in situation comedy television shows (Russell and Stern 2006). Finally, a recent Jupiter Research survey found that though viral marketing campaigns increased brand awareness, only $15 \%$ were reported to motivate consumers to repeat the marketing message to others (Marketing News 2007). Although such campaigns might cause consumers to be more likely to buy, it is rare that they are likely to repeat the message and thus influence possible purchases of other consumers.

\section{Public Policy Discussion}

\section{Degree of Consumer Injury}

In general, masked marketing practices are likely to mislead reasonable consumers materially and thus violate the deception statement. However, the FTC's statement notes that as a matter of policy, when consumers can easily evaluate the product or service and the product or service is inexpensive and frequently purchased, the FTC will carefully consider whether to bring an enforcement action. Thus, although consumer injury is not required under the deception statement, it can be an important factor for the FTC's consideration of whether to invest the resources necessary to pursue a particular case. When consumers can easily evaluate inexpensive products, the FTC believes that there is little incentive for advertisers to misrepresent the product because the long-term goal should be to encourage repeat purchases. If consumers learn about masked marketing and are unhappy about it, they may not repurchase a product if they were misled about the marketing origin of an initial communication.

Such market self-correction assumes that many, if not most, consumers remember the initial deception for particular products, even though they buy and use thousands of products every year, often with little involvement in any particular purchasing decision. It also ignores the injury of short-term diversion of consumers to make at least one purchase they otherwise may not have made. Several courts have recognized a similar concept called "initial interest confusion" in trademark law. Marketers use deceptively similar marks at least initially to confuse consumers as to the source of the goods. Even if consumers realize the correct product identity before purchase, several courts have held that the initial diversion of consumer interest is actionable because some consumers simply choose the new product despite their initial intentions to purchase the wellknown brand (Rothman 2005). Footnote 58 of the deception statement similarly talks about wrongful diversion of consumers, but the text of the statement suggests that preventing a one-time diversion for inexpensive, frequently purchased consumer goods is not an enforcement priority.

However, the statement does not preclude FTC action in such cases. So-called fly-by-night marketers live by shortterm deception with a long-term plan to offer one deceptively promoted product after another and not to seek repeat purchasers. Although the injury to individual consumers may be financially small, the total injury to the market may be sufficiently substantial to justify FTC action. Furthermore, the actions of such marketers over time also may justify FTC enforcement to prevent future deception involving seemingly unrelated products. In some cases, a few consumers may suffer large injury. The FTC condemned furnace repair companies whose sales agents posed as inspectors offering a free inspection. The catch was that the "inspectors" would then disassemble the furnaces and refuse to reassemble them until a service contract was purchased (Davis Furnace Co. 1961; Holland Furnace Co. 1958).

The FTC pursued several early television infomercials for inexpensive products not only because of their decep- 
tive format but also for misleading or unsubstantiated claims about the product. The products in these cases were inexpensive, and some were easily evaluated, such as sunglasses (JS\&A Group Inc. 1989), a book on government grants and loans (James R. Wyatt 1993), and systems for learning to read or developing a photographic memory (Mega Systems Int'l Inc. 1998). Other inexpensive products were somewhat more difficult to evaluate through product use, such as weight loss, disease prevention, and baldness remedies. Because of the relatively long periods of evaluation, the existence of many other factors that might influence the condition, and the lack of strict objective criteria (even weight loss can include losing weight but gaining muscle), evaluating these latter products is akin to evaluating credence attributes rather than experience attributes (Petty 1992, pp. 36-37). However, after the adoption of the deception statement, only approximately $10 \%$ of FTC advertising cases involved deception regarding search or experience attributes for frequently purchased products (Petty 1992).

\section{Masked Marketing and Specific Marketing Regulations}

Some marketing practices are presumed to cause sufficient consumer injury to justify specific regulation of those practices. For example, the endorsement guidelines on their own terms apply to any masked marketing practices that involve advertising (albeit disguised), and the FTC has stated it will apply the guidelines to word-of-mouth marketing situations as well. In addition, some practices, such as sweepstakes (Taylor and Kopp 1991), distance marketing, and telephone and e-mail marketing, are regulated by specific rules.

For example, the FTC's Door-to-Door Sales Rule requires that sellers provide a three-day cooling-off period for sales made outside the ordinary place of business and that their sales agents inform consumers about the period and how to exercise their right to cancel the transaction. At first glance, this would appear not to apply to buzz marketing because the agents do not consummate the sales; that is, they merely suggest that consumers "check out" the product. However, in the case in which a buzz agent shows the consumer how to order the product online, the requirements of the rule would appear to be satisfied. Thus, the marketer would be liable for financial penalties for failing to provide information on the three-day cancellation period.

Similarly, a buzz agent who telephoned a friend to "talk up" a product would need to follow the telemarketing laws just as one who e-mailed friends would need to follow the rules on commercial e-mailing. For telemarketing, several U.S. states have "get-to-the-point" laws, which require callers to identify their purpose within a short time. A few states follow the European practice of requiring cooling-off periods for all telephone-solicited sales (Cain 1994). The FTC Telemarketing Rule (16 C.F.R. § 310.4[d][2]) requires that sales calls be identified. However, it is not clear whether these rules would apply to calls that merely "talk up" a product without attempting to close the sale.

Under federal law, telephone solicitations only may occur between the hours of 8:00 A.M. and 9:00 P.M. and may not be harassing by repeat calls (16 C.F.R. $\$ 310)$, and cold calls to cell phones are prohibited (47 C.F.R. § 64; Cain 1996). Notably, activities of buzz agents might easily violate these provisions. Furthermore, many states, and now the FTC, offer a do-not-call list, which marketers are required to check before making telemarketing calls, unless they have a preexisting relationship with the customer. Perhaps buzz agents who call their friends will be able to claim a preexisting relationship even if they violate other telemarketing rules.

A court of appeals in Arizona has held that the use of an automatic dialing system to send commercial text messages to cell phones violates the Telephone Consumer Protection Act (Joffe v. Acacia Mortgage Corp. 2005). The court noted that the CAN-SPAM Act of 2003 may also apply to cell phone text messaging (Petty 2003). The CAN-SPAM Act allows marketers to send unsolicited commercial e-mail but prohibits misleading header, "from," or "subject" lines, and it also requires that consumers be given a method for opting out of receiving e-mail messages from the same source. The law also prohibits marketers from harvesting e-mail addresses from Web sites (typically using robot crawlers), relaying commercial e-mails through other computers without permission, and using programs to generate possible e-mail addresses by combining popular names with e-mail locations (15 U.S.C. $§ 7701)$. Viral marketers that rely on e-mail communications need to make sure their agents do not run afoul of these laws. Use of a misleading subject line and the lack of notification on how to stop future e-mails are two requirements that agents are likely to violate.

\section{Policy Recommendations}

The foregoing discussion suggests that masked marketing practices can often violate the FTC's deception statement, endorsement guidelines, and other regulations of specific marketing practices. Nevertheless, we offer three public policy recommendations. First, the FTC should update its deception statement and endorsement guidelines to include modern masked marketing examples, clarifying whether the marketing nature of communications might be deceptive. New examples should illustrate specifically how the classic law enforcement principles apply to examples involving recent technology, such as cell phone texting and Internet communications of various forms. These updates also should clarify circumstances under which marketers will be held responsible for statements made by their agents. ${ }^{1}$ If politics prevent the FTC from doing this, the Council of Better Business Bureaus may be able to more easily update its guidelines.

\footnotetext{
${ }^{1}$ Ordinary consumer endorsers must truthfully describe their experiences with the endorsed product but are not required to reasonably investigate or substantiate the effectiveness of the product. The FTC consent agreements have required celebrity endorsers to make a reasonable inquiry into the truth of the claims (e.g., Cooga Mooga Inc. 1978), and occasional private lawsuits have held celebrities financially liable for negligence in making misleading claims when the advertiser cannot be located or is in bankruptcy (Kertz and Ohanian 1991). Expert endorsers must actually possess appropriate expertise and rely on it when making their endorsements (16 C.F.R. 255.3[b]).
} 
Second, the FTC should clarify the types of commercial connections it believes are currently unexpected by consumers. If a marketing agent does not disclose his or her status, is there a de minimis connection (e.g., a coupon for pennies off the retail price) that is so small that consumers would not expect the incentive to bias their views? The FTC has already recognized that "psychic" rewards, such as being selected to appear in a television commercial, might be an unexpected commercial connection that should be disclosed (16 C.F.R. $\$ 255.5$ ). Perhaps being part of a select group of consumers that receive new products before the general public should also be disclosed. Market research could be conducted to determine whether such selection biases the product evaluations of consumers compared with those who are not selected to be in such an "elite" group.

Third, the FTC should clarify its position on product placements and advertainment. In some cases, such as video games, product placement often appears clearly as advertising or at least as a re-creation of advertising to enhance the game's realism. The FTC should clarify whether it will evaluate and enforce the content of such advertising images. Similarly, the FTC should clarify whether it will examine the content of product-related statements made during celebrity interviews or made by characters in movie or television programming. Roehm, Roehm, and Boone (2004) suggest that these two types of product mentions are stored differently in memory, with the "celebrity plug" being remembered by product category but the story line use being stored in memory about the television show. The authors conclude that for marketers who want to stimulate future purchases of their brand, the celebrity plug may be more useful than the character mention of the brand.

More typical product placements involve only a brief view and perhaps use of a product in passing as part of entertainment. The characters do not praise the product or mention anything about its performance or attributes. To date, research indicates that these placements may not even be consciously perceived or remembered by consumers, but they might still have an emotional impact on purchasing decisions. For example, visual-only placements, typically the lowest-priced placements, are processed by viewers at a low level of cognition and therefore may lead to stronger emotional and purchase-intent effects than more elaborate placements that mention the product by name or show the product in use (Balasubramanian, Karrh, and Patwardhan 2006). Research evidence in consumer behavior has long demonstrated the positive effects of pictorial and vivid imagery used in advertisements on consumer attitudes (Kisielius and Sternthal 1986; Mitchell and Olson 1981). Arguably, such product placements might qualify as a form of "mental marketing," as we discussed previously. Because these practices may be beyond the realm of objective claim verification in current deception policy, any such evaluation may need to come from the FCC or the FTC's consumer unfairness authority (FTC 1984, codified in 15 U.S.C. $45[\mathrm{n}])$. However, the FTC (2005) has made it clear that it will not pursue any such placements for deceptively omitting a disclosure that the placement was a paid one.

\section{Conclusion}

Although buzz and viral marketing currently are touted as the latest methods for addressing the twin problems of consumer skepticism and consumer overload with marketing communications (e.g., clutter), masked marketing has been practiced for most of the twentieth century, if not longer. In some cases, legal and regulatory requirements are clear; marketing messages must not be disguised as third-party opinion, and agents promoting products must make it clear if they are getting paid to do so (or own the marketing company), if these facts are not well understood by consumers.

Unfortunately, the practice of marketing advances at a pace far faster than that of marketing regulation. For this reason, marketers must rely on existing laws pertaining to testimonials, personal selling, telemarketing, and commercial e-mail to address modern practices that, though similar, are also somewhat different. Careful analysis of the principles expressed in these laws provides reasonable guidance at this point for modern masked marketing practices. Updating existing materials with modern examples would help clarify when legal challenge may be likely.

Finally, it seems clear that as new marketing practices are developed, there needs to be research regarding these practices. Do consumers recognize these practices as marketing messages and react with the usual skepticism? Alternatively, because "ordinary people" and even friends or perceived friends (e.g., television characters) are involved, do consumers find these messages to be more persuasive than readily recognizable marketing messages? Are masked marketing messages even perceived as factual messages at all, or are they processed as opinions of other people? If the latter is true, how does that processing differ from the processing of recognizable marketing messages, and is this a concern for public policy makers? Does simply encouraging consumers, perhaps with a small reward, to talk about a new product predispose them to develop more positive attitudes or beliefs about the product or to communicate more positive product messages than those without marketer encouragement? Would consumers truly internalize such product beliefs and attitudes as a result of practices or simply identify peripherally with the company or brand? Finally, at what level or type of reward do most people believe that other people would become biased, whether conscious of that bias or not?

Ultimately, the long-term success of masked marketing techniques and the need for their regulation depend on the answers to these questions. In addition, it would be useful to conduct research comparing the relative effectiveness of various forms of masked marketing. We found only one study that compared the effectiveness of a product mention by a character within the story line of a television program (an active product placement) with that of a celebrity product plug within a talk show (a poser, if the celebrity was paid) (Roehm, Roehm, and Boone 2004). As we noted previously, the study results suggest that the two types of product mentions are stored differently in memory and that the celebrity plug would be more effective in stimulating sales because it is remembered with the product rather than with the entertainment program. 
Misleading marketing practices have been around for a long time; as a result, consumers have become increasingly skeptical of marketing, and government agencies (as well as the industry) have pursued enforcement and regulations in an attempt to control misleading claims. When considering masked marketing, policy makers, marketers, and consumers should consider whether they want a similar result for this type of practice. By adopting such practices, marketers make it more likely that consumer skepticism will increase about any information provided about a product or service, whether obviously advertising or apparently from an independent third party. As with advertising, the longterm result may be that such practices become less effective. However, the problem of misleading advertising is not contained within the sphere of marketing and consumers. The practice of masked marketing may cause increased skepticism about how people relate to strangers and acquaintances and how people relate to one another in person and on Web sites. This no longer is a question of what type of marketing system society wants to have but rather of how much influence the marketing system should have over the type of society we enjoy.

\section{References}

A.A. Friedman Co. (1968), 74 F.T.C. 1056.

Abelson, Jenn (2005), "The Offer's in the Mail," Boston Sunday Globe, (June 12), A1, A25.

Adelstein, Jonathan S. (2005), “Fresh Is Not as Fresh as Frozen': A Response to the Commercialization of American Media," remarks before the American Media Institute, (May 25), (accessed October 25, 2007), [available at http://hraunfoss.fcc. gov/edocs_public/attachmatch/DOC-258962A1.pdf].

Andrews, J. Craig and Thomas J. Maronick (1995), "Advertising Research Issues from FTC Versus Stouffer Foods Corporation," Journal of Public Policy \& Marketing, 14 (Fall), 301-309.

Associated Press (2005), "Sneaking Ads into Games," (accessed November 14, 2005), [available at http://www.wired.com/news/ business/0,1367,69498.00.html].

Balasubramanian, Siva K. (1994), "Beyond Advertising and Publicity: Hybrid Messages and Public Policy Issues," Journal of Advertising, 23 (4), 29-46.

, James A. Karrh, and Hermant Patwardhan (2006), “Audience Response to Product Placements: An Integrative Framework and Future Research Agenda," Journal of Advertising, 35 (3), 115-41.

Bandler, James (2005), "Advice for Sale: How Companies Pay TV Experts for On-Air Product Mentions," The Wall Street Journal, (April 19), A1.

Bearden, William O., Richard G. Netemeyer, and Jess E. Teel (1989), "Measurement of Consumer Susceptibility of Interpersonal Influence," Journal of Consumer Research, 15 (March), 473-81.

Bonzai.com Software (2001), NAD Case No. 3797C (October 7).

Braswell, A. Glen, et al. (2006), (U.S. District Court, Central District of California, Western Division) FTC Settlement and Final Order, FTC Matter No. X030059, Civil Action No. CV 033700-DT (PJWx), (January 30).

Brookfield Communications v. West Coast Entertainment Corporation (1999), 174 F.3d 1036-1066 (9th Cir.).
Broyles, Sheri F. (2006), "Misplaced Marketing: Misplaced Paranoia over Subliminal Advertising: What's the Big Uproar This Time?" Journal of Consumer Marketing, 23 (6), 312-13.

Cain, Rita Marie (1996), "Recent Developments in Telemarketing Regulation," Journal of Public Policy \& Marketing, 15 (Spring), 135-41.

(1994), "Call Up Someone and Just Say Buy: Telemarketing and the Regulatory Environment," American Business Law Journal, 31 (4), 641-98.

Calfee John and Debra Ringold (1994), "The Seventy Percent Majority: Enduring Consumer Beliefs About Advertising," Journal of Public Policy \& Marketing, 13 (Fall), 228-38.

Campbell, Angela J. (2006), "Restricting the Marketing of Junk Food to Children by Product Placement and Character Selling," Loyola of Los Angeles Law Review, 39 (1), 447-506.

Carl, Walter J., Jr. (2006), “To Tell of Not to Tell? Assessing the Practical Effects of Disclosure for Word-of-Mouth Marketing Agents and Their Conversational Partners," summary report, (accessed October 25, 2007), [available at http://www. waltercarl.neu.edu/downloads].

Churchill, Gilbert A., Jr., and George P. Moschis (1979), “Television and Interpersonal Influences in Adolescent Consumer Learning," Journal of Consumer Research, 6 (June), 23-35.

Collins, Clayton (2004), "Lines Blur Between Ads and Articles," Christian Science Monitor, (May 27), (accessed October 19, 2004), [available at http://www.csmonitor.com/2004/0527/ p11s02-ussc.htm].

Comcast Corp. (2007), FCC No. DA 07-4005, (September 21).

Commercial Alert (2003a), "Complaint, Request for Investigation, and Petition for Rulemaking to Establish Adequate Disclosure of Product Placement on Television," submitted to the Federal Communications Commission, (September 30), 1-12.

(2003b), "Request for Investigation of Product Placement on Television and for Guidelines to Require Adequate Disclosure of TV Product Placement," submitted to the Federal Trade Commission, (September 30), 1-17.

(2005), "Request for Investigation of Companies That Engage in 'Buzz Marketing,"' submitted to the Federal Trade Commission, (October 18), 1-6.

Cooga Mooga Inc. (1978), 92 F.T.C. 310, order modified, 98 F.T.C. 814 (1981).

Creamer, Matthew (2005), "Foul Mouth: Stealth Marketers Flirt with Law," Advertising Age, (October 3), 6.

Cyr, Diane (1999), "Sweeps Saga: PCH and AFP Plan for Future in the Wake of Public Uproar," Direct, (September 30), (accessed April 21, 2005), [available at http://www.directmag. com/mag/marketing_sweeps_saga_pch/].

Darke, Peter R. and Robin J.B. Ritchie (2007), "The Defensive Consumer: Advertising Deception, Defensive Processing, and Distrust," Journal of Marketing Research, 44 (February), 114-27.

Davis Furnace Co. (1961), 59 F.T.C. 583.

Direct Marketing Association (2005), "Economic Impact: U.S. Direct Marketing Today," (accessed October 25, 2007), [available at http://www.the-dma.org/cgi/registered/research/ libres-ecoimp2003.shtml].

Dobele, Angela, David Toleman, and Michael Beverland (2005), "Controlled Infection! Spreading the Brand Message Through Viral Marketing," Business Horizons, 48 (2), 143-49. 
Encyclopaedia Britannica, Inc. v. FTC (1979), 605 F.2d 964 (7th Cir.), cert. denied, 445 U.S. 934 (1980).

Enright, Allison (2005), "Stats: To Your Places Everyone," Marketing News, (July 15), 4.

Ford, Gary T. and John E. Calfee (1986), "Recent Developments in FTC Policy on Deception," Journal of Marketing, 50 (July), 82-103.

Friestad, Marian and Peter Wright (1994), "The Persuasion Knowledge Model: How People Cope with Persuasion Attempts," Journal of Consumer Research, 21 (1), 1-31.

FTC (1983), "FTC Policy Statement on Deception," appended to Cliffdale Associates, Inc., 103 F.T.C. 110, 174 (1984), (accessed December 1, 2006), [available at http://www.ftc.gov/ bcp/policystmt/ad-decept.htm].

- (1984), "Policy Statement on Unfairness," appended to International Harvester Co., 104 F.T.C. 949, 1070 (1984), (accessed October 25, 2007), [available at http://www.ftc.gov/ bcp/policystmt/ad-unfair.htm].

- (2002), Re: Commercial Alert complaint, "Requesting Investigation of Various Internet Search Engine Companies for Paid Placement and Paid Inclusion Programs," (June 27), (accessed December 19, 2006), [available at http://www.ftc. gov/os/closings/staff/commercialalertattatch.htm].

(2005) Re: Commercial Alert petition, "Request for Investigation of Product Placement on Television and for Guidelines to Require Adequate Disclosure of TV Product Placement," (February 10), (accessed December 19, 2006), [available at http://www.ftc.gov/os/closings/staff/050210productplacemen. pdf].

(2006) Re: Commercial Alert petition, "Request for Investigation of Companies That Engage in 'Buzz Marketing,", (December 7), (accessed December 19, 2006), [available at http://www.ftc.gov/os/closings/staff/061211staffopinionto commercialalert.pdf].

FTC v. Direct Marketing Concepts Inc. (2004), No. 04-CV11136-GAO (D. Mass.) (complaint filed June 3, 2004; preliminary injunction granted June 23, 2004), (accessed October 25, 2007), [available at http://www.ftc.gov/os/caselist/0233138/ 0233138.htm].

FTC v. Standard Education Society (1937), 302 U.S. 112.

FTC v. Window Rock Enterprises Inc. et al. (2004), No. CV048190 DSF (JTLx) (C.D. Cal.) (complaint and stipulated interim agreement and order filed September 30, 2004), (accessed October 25,2007$)$, [available at http://www.ftc.gov/os/caselist/ windowrock/windowrock.shtm].

Georgetown Publishing House Ltd. Inc. (1996), 122 F.T.C. 392.

Gogoi, Pallavi (2006), "Wal-Mart's Jim and Laura, the Real Story," BusinessWeek, (October 6), (accessed December 5, 2006), [available at http://www.businessweek.com/bwdaily/ dnflash/content/oct2006/db20061009_579137.htm].

Goodman, Ellen P. (2007), "Peer Promotions and False Advertising Law," South Carolina Law Review, 58 (Summer), 683-707.

Gynex Corp. v. Dilex Inst. of Feminine Hygiene (1936), 85 F.2d 103 (2d Cir.).

Hammond, John S., Ralph L. Keeney, and Howard Raiffa (2006), "The Hidden Traps in Decision Making," Harvard Business Review, 84 (1), 118-26. (Reprinted from 76 [5], 47-58 [1998].)

Holland Furnace Co. (1958), 55 F.T.C. 55.

Horowitz, Bruce (2005), "P\&G Buzz Marketing Unit Hit with Complaint," USA Today, (October 19), 1B.
Hoy, Mariea Grubbs and J. Craig Andrews (2004), "Adherence of Prime-Time Televised Advertising Disclosures to the "Clear and Conspicuous' Standard: 1990 Versus 2002," Journal of Public Policy \& Marketing, 23 (Fall), 170-82.

James R. Wyatt (1993), 118 F.T.C. 117.

Joffe v. Acacia Mortgage Corp. (2005), 121 P.3d 831 (Ct. of App. Az. Div. 1, Depart. E).

JS\&A Group Inc. (1989), 111 F.T.C. 529.

Kaikati, Andrew M. and Jack G. Kaikati (2004), "Stealth Marketing: How to Reach Consumers Surreptitiously," California Management Review, 46 (4), 6-22.

Kertz, Consuelo Lauda and Roobina Ohanian (1991), "Recent Trends in the Law of Endorsement Advertising: Infomercials, Celebrity Endorsers and Nontraditional Defendants in Deceptive Advertising Cases," Hofstra Law Review, 19 (3), 603-656.

Khermouch, Gerry and Jeff Green (2001), "Buzz Marketing," BusinessWeek, (July 30), 50-57.

Kisielius, Jolita and Brian Sternthal (1987), "Examining the Vividness Controversy: An Availability-Valence Interpretation," Journal of Consumer Research, 12 (4), 418-31.

Kopytoff, Verne (2002), “Sites Told to 'Fess Up,"' San Francisco Chronicle, (June 29), B1.

La Pastina, Antonio C. (2001), "Product Placement in Brazilian Prime Time Television: The Case of the Reception of a Telenovela," Journal of Broadcasting and Electronic Media, 45 (Fall), 541-57.

Lindstrom, Martin (2005), Brand Sense: Build Powerful Brands Through Touch, Taste, Smell, Sight and Sound. New York: The Free Press.

Marketing News (2007), "Viral Marketing Outlook Ill," (October 15), 6 .

Maronick, Thomas J. (1990), "Copy Tests in FTC Deception Cases: Guidelines for Researchers," Journal of Advertising Research, 31 (December), 9-17.

Media Arts Int'l Ltd. v. Trillium Health Products (1992), 25 U.S. P.Q. 2d 1764 (E.D. Pa.).

Mega Systems, Int'l, Inc. (1998), 1998 FTC LEXIS 207.

Menin, Bruce (2005), "Here's Looking at You, Kids," Campaign for a Commercial-Free Childhood, (March 18), (accessed October 26, 2007), [available at http://www.commercialexploitation. org/news/articles/hereslooking.htm].

Mitchell, Andrew A. and Jerry C. Olson (1981), "Are Product Attribute Beliefs the Only Mediator of Advertising Effects on Brand Attitude?" Journal of Marketing Research, 18 (August), 318-32.

Moore, Elizabeth S. and Victoria J. Rideout (2007), "The Online Marketing of Food to Children: Is It Just Fun and Games?" Journal of Public Policy \& Marketing, 26 (Fall), 202-220.

Moore, Timothy E. (1982), "Subliminal Advertising: What You See Is What You Get," Journal of Marketing, 46 (Spring), $38-47$.

National Housewares, Inc. (1977), 90 F.T.C. 512.

Nelson, M.R. (2002), "Recall of Brand Placements in Computer/ Video Games," Journal of Advertising Research, 42 (2), 80-92.

Nielsen (2007), "Word-of-Mouth the Most Powerful Selling Tool: Nielsen Global Survey," (accessed October 26, 2007), [available at http://www.nielsen.com/media/2007/pr_071001.html]. 
Obermiller, Carl and Eric R. Spangenberg (2000), "On the Origin and Distinctness of Skepticism Toward Advertising," Marketing Letters, 11 (4), 311-22.

- and Douglas L. MacLachlan (2005), "Ad Skepticism: The Consequences of Disbelief," Journal of Advertising, 34 (3), 7-18.

Petty, Richard E. and John T. Cacioppo (1986), Communication and Persuasion: Central and Peripheral Routes to Attitude Change. New York: Springer-Verlag.

Petty, Ross D. (1992), The Impact of Advertising Law on Business and Public Policy. Westport, CT: Quorum Books.

(2003), "Wireless Advertising Messaging: Legal Analysis and Public Policy Issues," Journal of Public Policy \& Marketing, 22 (Spring), 71-83.

Phillips, Lynn W. and Brian Sternthal (1977), "Age Differences in Information Processing: A Perspective on the Aged Consumer," Journal of Marketing Research, 14 (November), 444-57.

Pringle, Hamish (2004), Celebrity Sells. West Sussex, UK: John Wiley \& Sons.

Roehm, Michelle L., Harper A. Roehm Jr., and Derrick S. Boone (2004), "Plugs Versus Placements: A Comparison of Alternatives for Within Program Brand Exposure," Psychology \& Marketing, 21 (1), 17-28.

Rothman, Jennifer E. (2005), "Initial Interest Confusion: Standing at the Crossroads of Trademark Law," Cardozo Law Review, 27 (October), 105-191.

Russell, Cristel Antonia and Barbara B. Stern (2006), "Consumers, Characters, and Products: A Balance Model of Sitcom
Product Placement Effects," Journal of Advertising, 35 (1), $7-21$.

Shimp, Terence A. (2007), Advertising, Promotion, and Other Aspects of Integrated Marketing Communications. Mason, $\mathrm{OH}$ : Thomson/South-Western.

60 Minutes (2004), "Undercover Marketing Exposed," (July 25), (accessed June 19, 2006), [available at http://www.cbsnews. com/stories/2003/10/23/60minutes/printable579657.shtml].

Steinberg, Brian and James Bandler (2004), "Blurring the Line? Magazines Face New Pressure as Marketers Seek to Blend Advertisers with Content," The Wall Street Journal, (August 9), B1.

Sutton, Richard C. and Barbara Zack (2006), Best Practices in Branded Entertainment: Case Studies and Accountability. New York: Association of National Advertisers.

Synchronal Corporation (1994), FTC Docket No. 9251 (February $3)$.

Taylor, Charles R. and Steven W. Kopp (1991), "Games, Contests, and Sweepstakes Run Afoul: A State of Legal Disorder,' Journal of Public Policy \& Marketing, 10 (Spring), 199-213.

Teinowitz, Ira (2005), "CARU Targets Product Placement and Cartoon Ads," Advertising Age, (September 16), [available at http://www.adage.com].

United States v. Reader's Digest Association (1981), 662 F.2d 955 (3d Cir.), cert. denied, 455 U.S. 908 (1982).

Vranica, Suzanne (2005), "Trends: Advertising; Anywhere, Anytime," The Wall Street Journal, (November 21), R6.

Walker, Rob (2004), "The Hidden (in Plain Sight) Persuaders," The New York Times, (December 5), 69. 